DE DE GRUYTER

OPEN

PESD, VOL. 8, no. 2, 2014

\title{
FREQUENCY OF THERMAL INVERSIONS BETWEEN SIRET AND PRUT RIVERS IN 2013
}

\author{
Pavel Ichim ${ }^{1}$, Liviu Apostol ${ }^{2}$, Lucian Sfîcă ${ }^{3}$, \\ Adriana-Lucia Kadhim-Abid ${ }^{4}$, Vasilică Istrate ${ }^{1}$
}

Keywords: thermal inversions, frequency,

\begin{abstract}
Temperature inversions represent complex phenomena, specific for depression forms of relief which introduce changes in vertical zoning (Apăvăloae, Apostle, Pîrvulescu, 1986 by stable air stratification (Erhan, 1981), because of their morphological features, this is due to the interdependence of general movement and characteristics of the active surface, being the cause of their production (Apăvăloae, et. al., 1984, 1986, 1987). The generation of thermal inversions, their intensity and frequency is a consequence of altitude topography, morphology, fragmentation, orientation and degree of closure to external drives. (Apăvăloae, Apostle, Pîrvulescu, 1988). Thermal inversions represent complex phenomena, specific to depression landforms that introduce changes within the vertical zoning (Apăvăloae, Apostol, Pîrvulescu, 1986) by stable air stratification (Matveev, 1958, Erhan, 1981, Yinghui Liu, 2002) where vertical thermal gradient is negative (Matveev, 1958), due to their morphological features, also as a consequence of the interdependance of general circulation and characteristics of the active surface, the cause of their generation (Apăvăloae, et. al., 1984, 1986, 1987).
\end{abstract}

\section{Introduction}

Thermal inversions are associated with stable stratification conditions or „most stable" (Matveev, 1985), to the air in the low troposphere, persitance of atmospheric stability conditions. The increase in temperature with altitude, and various characteristics of air humidity, clouds and thermal inversions result in the formation of the inversion layer, aerosol transport and wind speed (Yinghui, Liu, 2002).

\footnotetext{
${ }^{1}$ PhD. student, "Alexandru Ioan Cuza University", Iasi, Romania pavel_ichim@yahoo.com 2 Prof. PhD. "Alexandru Ioan Cuza University", Iasi, Romania

${ }^{3}$ Lect. PhD. "Alexandru Ioan Cuza University", Iasi, Romania

${ }^{4} \mathrm{PhD}$. Student, "Georghe Asachi” Tehnical University of Iași
} 
In some conditions, thermal inversions can occur by radiative cooling, advection of warm air masses over the layer of clod air, as depression relief and and morphometry (Kahl, 1990, quoted by Liu, 2002).

Producing thermal inversions, intensity and frequency is a consequence of altitude terrain morphology, fragmentation, orientation and degree of closure to external drives (Apăvăloae, et. al., 1988).

Normally, the atmposhpere is characterized by a decrease in the elevation of the air temperature, in most cases the temperature tends to rise in altitude, which is characterized by a negative or null vertical thermal gradient (Apăvaloae, et. al., 1994).

When the vertical thermal gradient is equal to 0 (zero), the air temperature is constant for a certain altitude difference isothermals are produced (Apostol, 1999), which represent „state of thermal instability of the atmosphere, neutral, have a a very low statistical probability of producing, the chances of determining them being reduced, these making the transition between the inversion layer and the air layer above the normal distribution of thermal gradients (Apostol, 1999).

Depending on the formation, thermal inversion phenomena are caused by a number of global factors felt throughout the year resulting from the roation of the Earth's radiative heat balamce seasonal and/or diurnal and seasonal variation of surface characteristicss underlaying assets. After the formation, thermal inversion phenomena include: radiation thermal inversions, nocturnal thermal inversions, winter thermal inversions and snow (spring) thermal inversions.

\section{Data and methods}

The studied area is represented mostly by the area between Prut and Siret valley containing a large part of the historical province of Moldova (fig. 1).

The interest area is placed about $3{ }^{\circ}$ latitude and about $2^{\circ}$ longitude, which provides a longitudinal climatic setting quite diverse.

The landscape is characterized by heights ranging between $0 \mathrm{~m}$ (in lower plain of Siret river and Prut river at the confluence of the Danube) and $586 \mathrm{~m}$ - Dealul Mare-Harlau (Peak Tudora).

Morphometric speaking, on the studied surface the most representative altitudinal class is between 100-200 m altitude, with a share of about $42.2 \%$ (Fig. 2 ) it is specific in the south of the territory and over watercourses. Lowest weight belongs to the altitude class which has altitudes above $500 \mathrm{~m}$ with a approximate rate of $0.1 \%$, these heights being specific for Dealu Mare Hârlău and for Culmea Doroșan from Colonele Tutovei. 


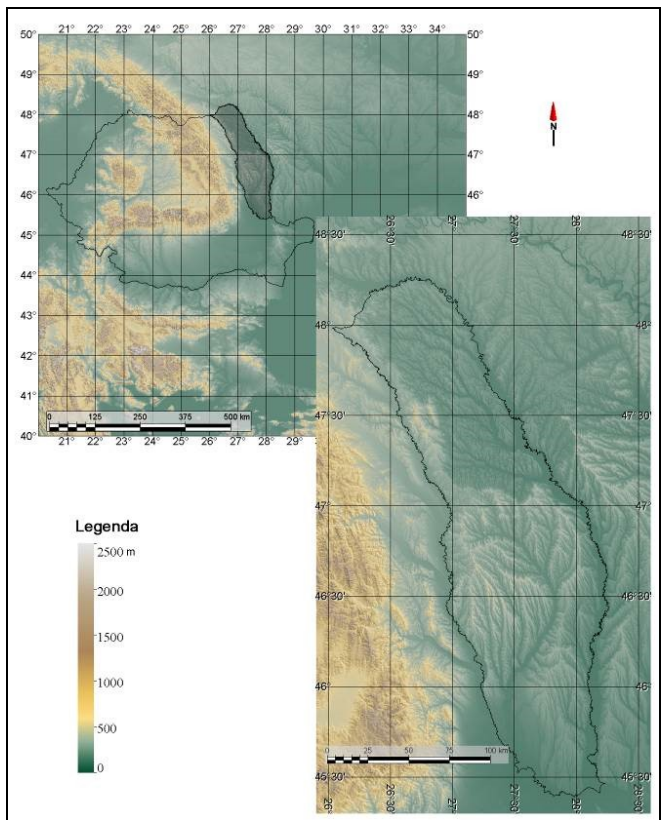

Fig. 1. Locating the study area in Romania

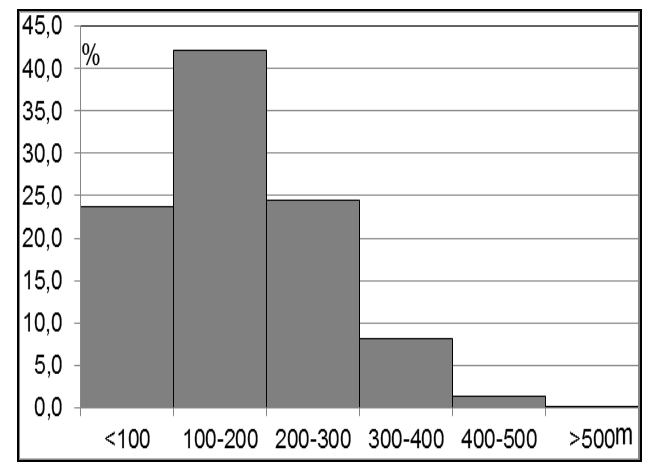

Fig. 2.The frequency distribution of elevation classes in the region between the rivers Siret and Prut

The experimental observation network includes 14 observation points including: two automatic weather stations (Cârja, and Mădârjac) and 12 data loggers (Larga Jijia, Dacia, Dancu, Ștefănești, Ciric, Răducăneni, Roșiești, Roman, Tudora, Păun, Ivănești, Deleni), (tab. 3.). 
First observations were conducted in Roman region, since December 2011 and the observations were aiming just a series of experiments regarding behaviour and recording of the data loggers, battery life autonomy, real time comparison between N.M.A. data and Roman meteorological station.

Observations were also realised at a 6 hour interval for Răducăneni, Larga Jijia and Roşiești points, starting the summer of 2011 but the data loggers fucntioned without meteorological shelters until November 2012. Thermal values registered were extremely high, thus forcing the team to shelter all data loggers mentioned above. $\mathrm{V}$

The present study assumed at first conceiving and designing mini weather shelters similar to those used on convetional meteorological platforms, shelters in which the data loggers were installed responsible for registering air temperature and humidity values at 1 hour interval.

Tab.1. Observation points that sum up the experimental observation grid

\begin{tabular}{|c|c|c|c|c|c|c|}
\hline Nr. Crt. & Station name & Type & ALT. & LAT. & LONG. & $\begin{array}{c}\text { Functioning } \\
\text { interval }\end{array}$ \\
\hline 1 & Cârja & s.m.a. & 21 & $46^{\circ} 09^{\prime}$ & $28^{\circ} 06^{\prime}$ & $08.2012->$ present \\
\hline 2 & Larga Jijia & senz. & 42 & $47^{\circ} 21^{\prime}$ & $27^{\circ} 22^{\prime}$ & $08.2011->$ present \\
\hline 3 & Dacia & senz. & 44 & $47^{\circ} 10^{\prime}$ & $27^{\circ} 32^{\prime}$ & $12.2012->$ present \\
\hline 4 & Dancu & senz. & 60 & $47^{\circ} 09^{\prime}$ & $27^{\circ} 40^{\prime}$ & $11.2012->$ present \\
\hline 5 & Ştefăneşti & senz. & 60 & $47^{\circ} 50^{\prime}$ & $27^{\circ} 14^{\prime}$ & $11.2012->$ present \\
\hline 6 & Ciric (Veneţia) & senz. & 63 & $47^{\circ} 09^{\prime}$ & $27^{\circ} 37^{\prime}$ & $12.2012->$ present \\
\hline 7 & Galaţi & S.M. & 68 & $45^{\circ} 28^{\prime}$ & $28^{\circ} 02^{\prime}$ & - \\
\hline 8 & Iaşi & S.M.*** & 104 & $47^{\circ} 10^{\prime}$ & $27^{\circ} 37^{\prime}$ & - \\
\hline 9 & Răducăneni & $\operatorname{sen} z^{*}$ & 136 & $46^{\circ} 57^{\prime}$ & $27^{\circ} 55^{\prime}$ & $06.2011->$ present \\
\hline 10 & Roşieşti & senz. & 142 & $46^{\circ} 26^{\prime}$ & $27^{\circ} 53^{\prime}$ & $06.2011->$ present \\
\hline 11 & Botoşani & S.M. & 161 & $47^{\circ} 44^{\prime}$ & $26^{\circ} 38^{\prime}$ & - \\
\hline 12 & Bacau & S.M. & 182 & $46^{\circ} 31^{\prime}$ & $26^{\circ} 54^{\prime}$ & - \\
\hline 13 & Roman & senz. & 205 & $46^{\circ} 56^{\prime}$ & $26^{\circ} 54^{\prime}$ & $12.2011->$ present \\
\hline 14 & Mădârjac & s.m.a.** & 252 & $47^{\circ} 03^{\prime}$ & $27^{\circ} 15^{\prime}$ & $10.2012->$ present \\
\hline 15 & Tudora & senz. & 256 & $47^{\circ} 30^{\prime}$ & $26^{\circ} 38^{\prime}$ & $10.2012->$ present \\
\hline 16 & Păun & senz. & 347 & $47^{\circ} 05^{\prime}$ & $27^{\circ} 39^{\prime}$ & $11.2012->$ present \\
\hline 17 & Mănăstirea Ivăneşti & senz. & 460 & $46^{\circ} 37^{\prime}$ & $27^{\circ} 24^{\prime}$ & $10.2012->$ present \\
\hline 18 & Deleni & senz. & 487 & $47^{\circ} 29^{\prime}$ & $26^{\circ} 50^{\prime}$ & $10.2012->$ present \\
\hline
\end{tabular}

*Temperature and humidity sensors

**Automated meterological stations

***N.M.A. meteorological stations that transmit in the sinoptic international flow.

The mini shelters have reduced dimensions compared to standard one $(30 \times 30 \times 30 \mathrm{~cm})$ and are realised entirely out of wood. After installation and 
assembly, two layers of white paint were applied on the outside of the shelter and of black paint on the inside.

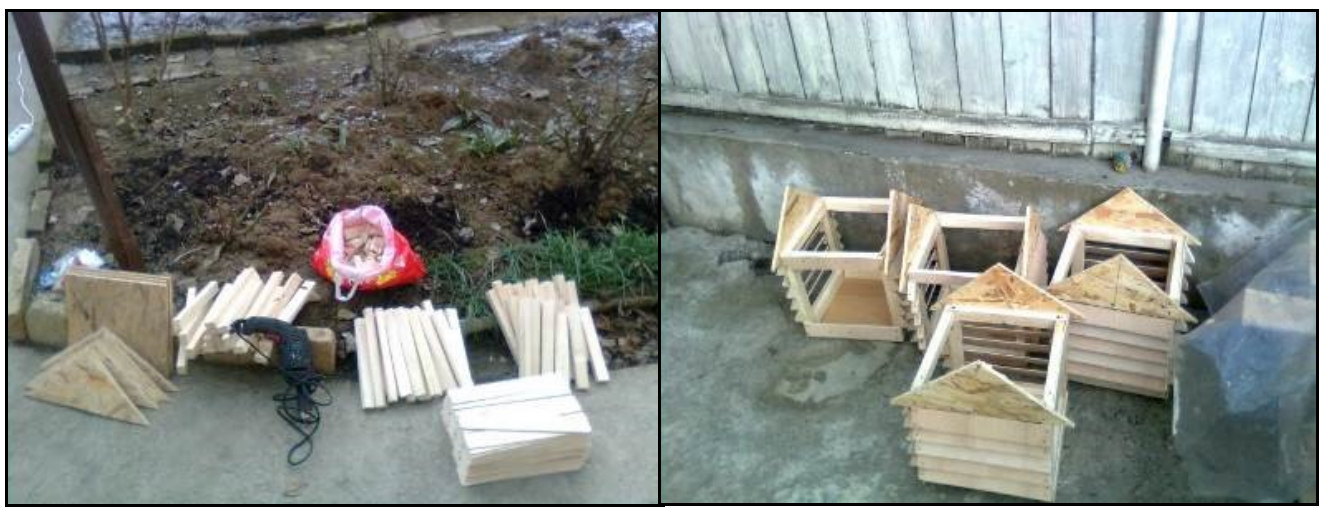

Fig. 3. Shelter materials (left) and shelter assembly (right)

Each shelter was installed at standar height observation $(2 \mathrm{~m})$ on grassy and open areas, avoiding as far as possible natural shading during the day (fig.4).
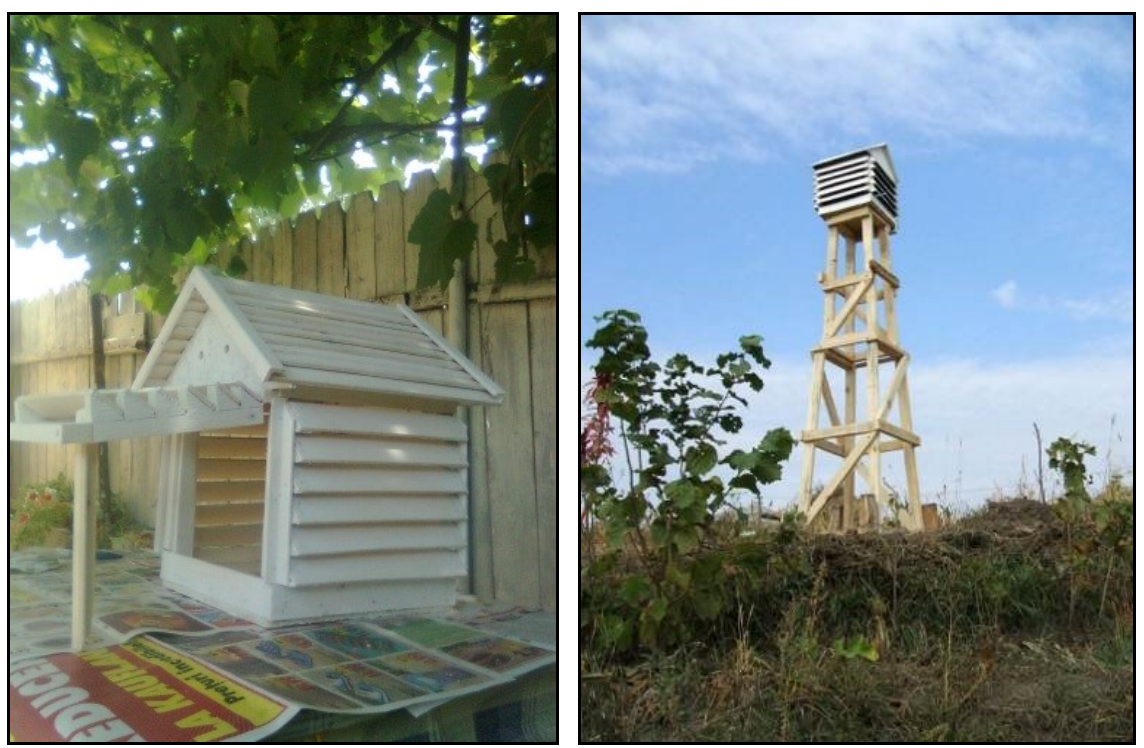

Fig. 4. Mini meteorological shelter (left); Mini-shelter at $2 \mathrm{~m}$ standard height at Tudora, Jud. Botoșani observation point (right) 
Instrumentation used. The experimental observation network includes 14 points installed by the team, to which we addeed the 4 weather stations that transmit in international synoptic flow. As mentioned above, the team tried an uniform coverage focused specially on a homogeneous altitudinal distribution with respect to the official meteorological network.

The altitude plateau ranging between 100- $200 \mathrm{~m}$ has the largest share (42.2\%) within the region. In this altitude range are three weather stations that are part of the official N.M.A. and transmit hourly data in international synoptic flow. In this altitudinal range, two experimental observation points (tab.2).

Răducăneni observation point (136 m) links profile between Păun and Valea Prutului observation points.

Tab. 2. Frequency classes of altitude and the number of observation points.

\begin{tabular}{ccc}
\hline $\begin{array}{c}\text { Altitudinal } \\
\text { class (m) }\end{array}$ & $\begin{array}{c}\text { Frequency } \\
(\mathbf{\%})\end{array}$ & $\begin{array}{c}\text { Number of } \\
\text { observation point }\end{array}$ \\
\hline$<100$ & 23,7 & 7 \\
$100-200$ & 42,2 & 5 \\
$200-300$ & 24,5 & 3 \\
$300-400$ & 8,2 & 1 \\
$400-500$ & 1,3 & 2 \\
$>500$ & 0,1 & 0 \\
\hline
\end{tabular}

Observational point Roșiești $(142 \mathrm{~m})$ is located in a tightly closed micro depression, very well enclosed that is drained by Idrici river, left affluent of Bârlad river. The enclosed depression landform gives it a unique character. This observation point connects Ivănești and Cârja observation points.

Higher altitude levels present lower heights, but as distribution pattern regarding the thermal inversion pheomena they are considered as crucial observation points. Within the region there are three observation points at altitudes greater than $300 \mathrm{~m}$.

Păun observation point operates at $347 \mathrm{~m}$ altitude which is considered as a junction point linking a series of profiles that we want to analyze the phenomenon of thermal inversion. It represents the bridge connecting the other observation points installed in Iassy alongside meteorological station of Iassy and Răducăneni observation point.

Ivănești observation point is located in Similea hills and function at $460 \mathrm{~m}$ altitude and it is also the link to the profile crossing from west to east the centralsouthern part region of the alignment Bacău - Ivănești - Roșiești - Cârja.

Highest altitude observatins within the region is $487 \mathrm{~m}$ at Deleni observation point located in Dealul Mare- Hârlău. This point connects, in terms of 
observations, the northen central part of the region. Observation points that we consider to be related are: in the north part Botoșani meteorological station, in the west Tudora observation point, north-east Ștefãnești observation point and in the south-east part Larga Jijia observation point, this relationship also having the highest relative latitude of aproximately $445 \mathrm{~m}$.

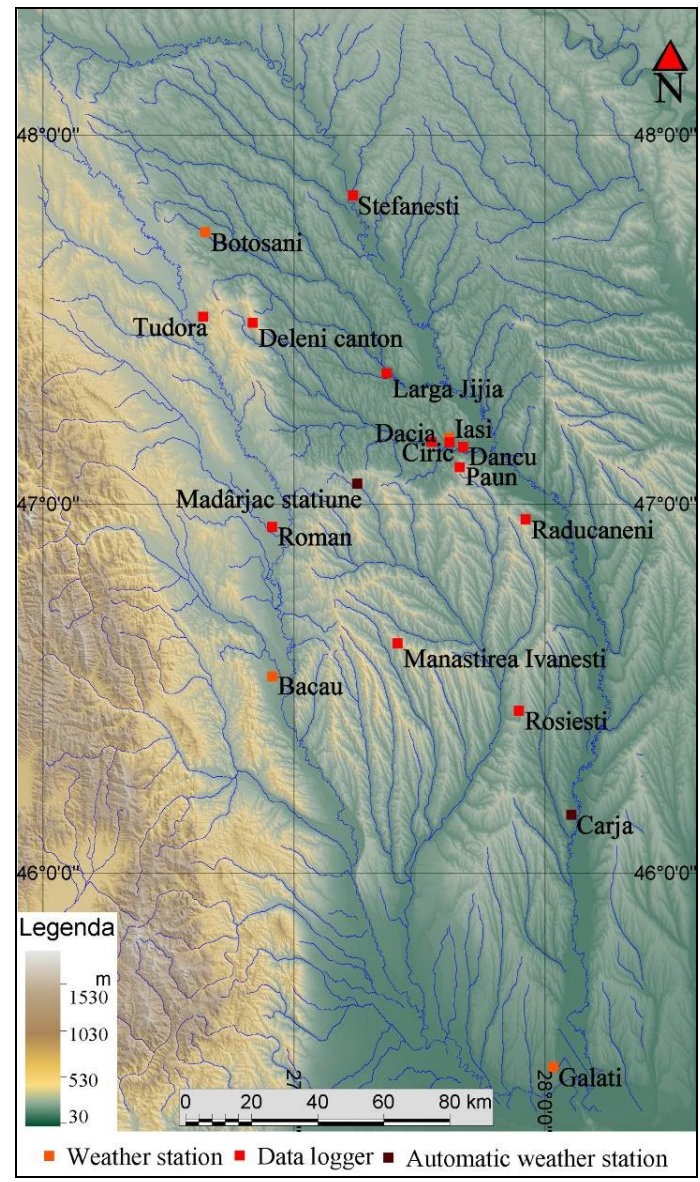

Fig. 5. Experimental observation network between Siret and Prut rivers

Cotnari observation point functions at $265 \mathrm{~m}$ altitude near Cotnari village. This point connects other observation points towards Siret river and Moldavia Plain, comparable with Deleni observation point. 
For this study hourly data obtained in the experimental observation network were used, together with a series of common observations from 2013. Th frequency of the thermal inversion phenomena were calculated for each profile.

\section{Results and discussions}

\subsection{Annual frequency of the thermal inversion phenomena}

In romanian literature there are no works regarding thermal inversion phenomenon at hourly occurence over a one year period of time. In most romanian literature in which reference is made on thermal inversion phenomena they are associated in most cases with particular periods of abrupt cooling, specific to the cold semester. On an annual basis there are a series of references regarding the thermal inversion phenomenon especially in the mountain area.

High latitudinal extension of the area offers a series of thermic differences which are induced first of all in the caloric radiative balance, air mass dynamics, morphological and morphometric parameters.

Using monthly mean data one can not determine the frequency of thermal inversion phenomena, especially those relative to radiation that produce in the first part of the day and they occur for a short period of time being easy dissipated after sunrise.

The entire region is distinguished by an average frequency of thermal inversion phenomenon of arpoximately $24.7 \%$ (Fig. 6).

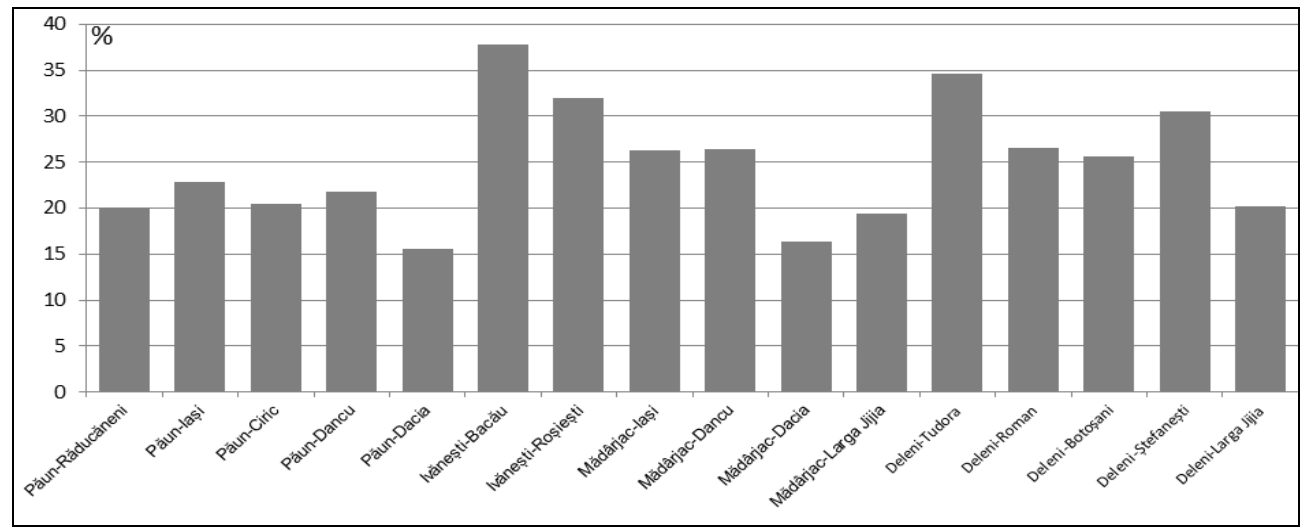

Fig. 6. Annual frequency of the thermal inversion phenomenon during 2013

For 2013 high frequencies of the inversion phenomenon are distinguished within the Siret corridor. In the year 2013, the hourly monitored inversion phenomenon present a frequency share of aproximately $38 \%$ on Ivănești-Bacău 
profle but little further north on Deleni-Roman profile, where phenomenon frequency was lower, reaching a frequency of $26 \%$. Lower inversion phenomenon frequency could be explained by the position of the observation point, that being located on the outskirts of the city. In these circumstances the heat generated by the anthropogenic surfaces is felt and it is influencing to some extent the thermic regime of this observation point. The northern part of Siret river can be distinguished through a frequency of the thermal inversion phenomenon of aproximately $34 \%$ on Deleni-Tudora profile.

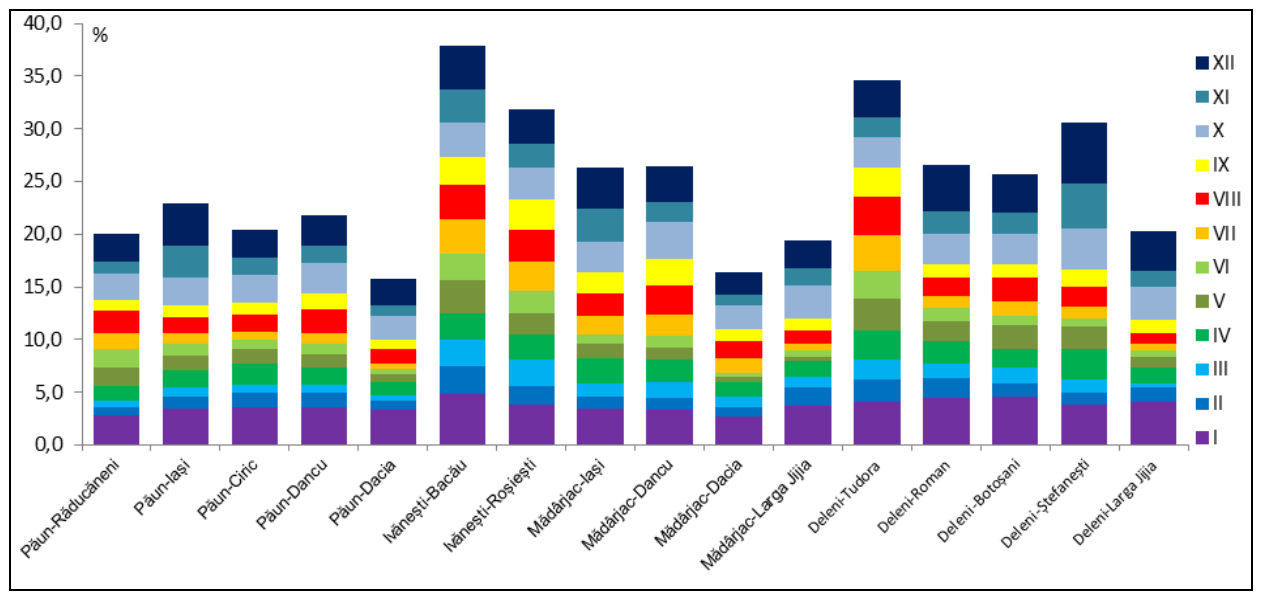

Fig. 7. Monthly frequence of thermal inversion phenomenon in 2013

Annual thermal inversions rate regime is characterised by large values mainly during the cold semester, with highest frequencies registered in January when profiles of Siret river observation points are highlighted. High frequency of situations regarding atmpospheric stability conditions generated by the anticyclones baric formations determine an increase of thermal inversion phenomenon frequency specially in ,closed" lowlands areas.

Within the profiles there is high frequency highlighted pertaining to the thermal inversion phenomenon during winter, especially during January and December (fig. 7).

Profiles Ivănești - Bacău, Deleni - Tudora, Ivănești - Roșiești and Deleni Ștefănești are distinguished by the highest values of thermal inversion phenomena with largest monthly values throughout the year (fig. 7).

In general, the spring season is poorly represented in the incidence of the thermal inversion phenomena except the analyzed profiles in correspondance with area of Siret river. Atmospheric dynamics is more intense during spring months 
which induces turbulent mixing of air masses existing in low troposphere, greatly reducing the frequency of thermal inversion phenomena.

Daily frequence of thermal inversion was calculated based on the average daily temperature values and compared on profiles for pairs of two stations. This type of frequency highlights very well the circumstances in which the phenomenon of thermal inversion that occurred in high intensity actively influenced the thermal regime of the air temperature in certain areas.

Through morphometric and morphological particularities, corroborated with the intense foehn phenomena specific to Dealul Mare Hârlău region, the number of situations with thermal inversion with strong intensity highlights the profiles Cotnari - Tudora, Cotnari - Roman, Deleni tudora and Ivănești - Roșiești. Within these sections we can distinguish high frequency in the daily average values, both during the cold semester as well as the hot one (fig. 8).

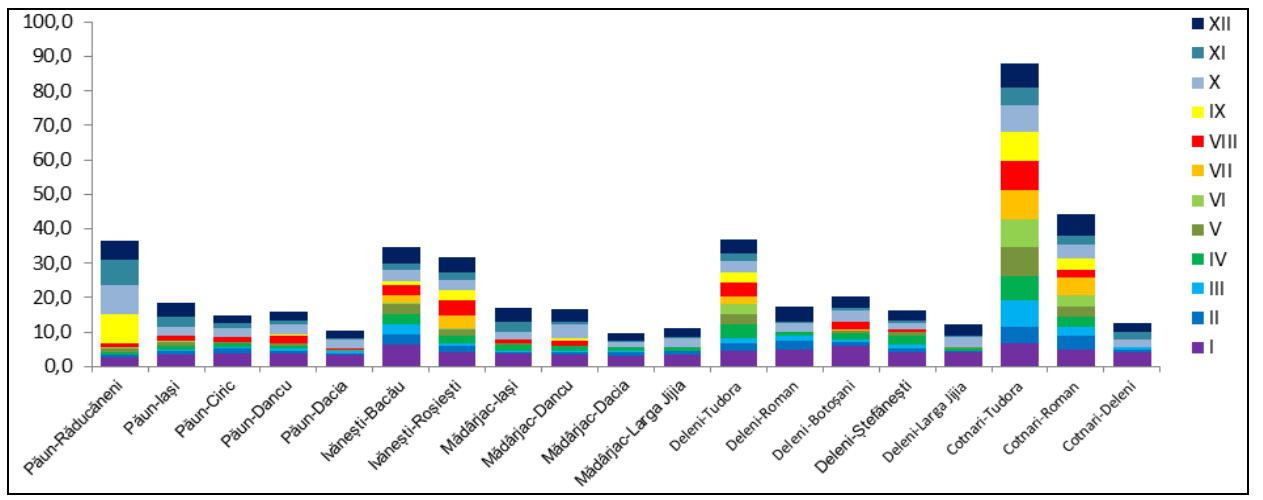

Fig. 8. Daily frequence of the thermal inversion phenomenon

The profile Păun - Răducăneni is characterized by extremely high frequencies of the year 2013 during the autumn season. The high incidence that thermal inversion phenomena generated low values for the daily average temperature of the autumn season.

Low frequencies outlined in the urban areas (Dacia observation point) and regions with large water surfaces. Although the phenomenon of thermal inversion occurs throughout the year in these profiles impact on the average daily temperature is not felt in the thermal regime.

Major differences in the evolution of thermal inversion phenomena frequency between the aisle areas, micro depression landforms and areas with a lower degree of fragmentation it can be deduced that to some extent the intensity degree pertaining to thermal inversion phenomenon. Thus, the thermal inversion episode is 
intense (even if radiation is a thermal inversion), the mean temperature of that day will be lower than those recorded at higher altitudes.

\subsection{Hourly frequency of the thermal inversion pheomenon}

2.2.1. Thermal inversion phenomenon frequency in the interval 01:00 - 06:00 a.m. During the year, the phenomenon of thermal inversion occurs cyclically reaching maximum frequency required in the thermal regime especially during the cold semester. In the daily regime, the thermal inversion frequency is intensified during night time. Thus, between the hours 01:00 to 06:00, the frequency of the thermal inversion phenomena recorded values exceeding the average annual frequencies. In these conditions we can equally distinguish all relationship analyzed, most common being those calculated on the corresponding profiles towards Siret river, which present specific frequencies of aproximately 50-55\% during 2013 between the hours 01:00 - 06:00.

The radiative inversions that manifest on the background of radiative cooling specific to the night regime induce a grow in frequency after midnight and continues to grow in frequency during the night until the early hours. Maximum frequency of manifestation for the thermal inversion occurs predominantly around 05:00. The time for maximum thermal inversion occurence depends on the time when the sun rises, is limited by atmospheric dynamics and local peculiarities of the relief, the frequency gradually ranging from one month to another.

In the thermal inversion frequency specific for 01:00 - 06:00 interval it stands out through almost equal frequencies for each month of the thermal inversion occurence throughout the year. Large frequencies can be observed (fig. 9 - 14) pertaining to thermal inversion phenomenon both for the cold season as well as the warm semester. High frequencies of thermal inversion phenomenon occur due to radiative cooling of the air in the immediate vicinity of the ground and especially on slopes where it becomes denser and is driven by gravity to the bottom of the valley. During situations characterized by atmospheric calm, the air is denser hence implicitly colder, it gets stratified favoring thermal inversion phenomenon occurence. 

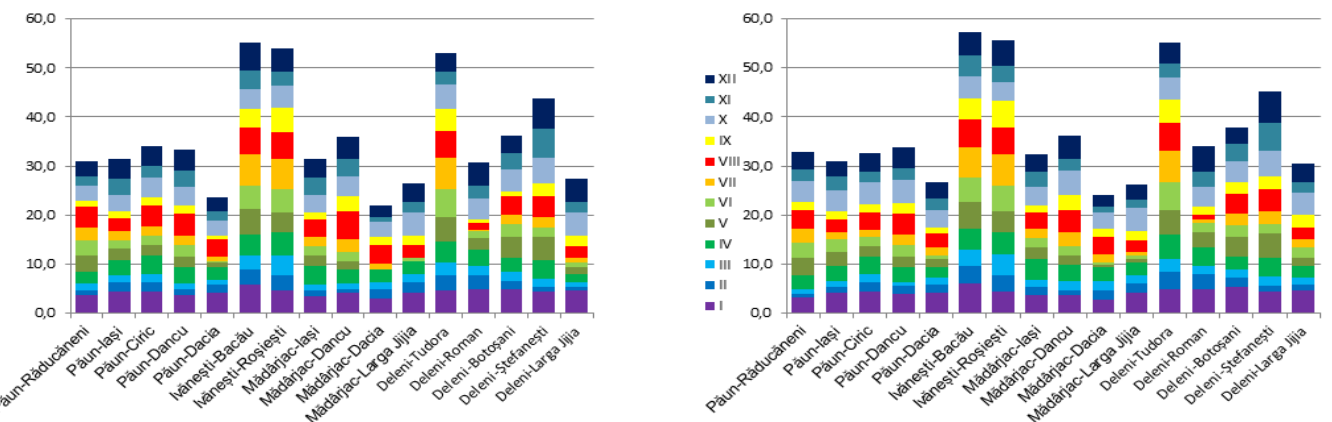

Fig. 9. Thermal inversion phenomena frequency at 01:00 a.m. Fig. 10. Thermal inversion phenomena frequency at 02:00 a.m.
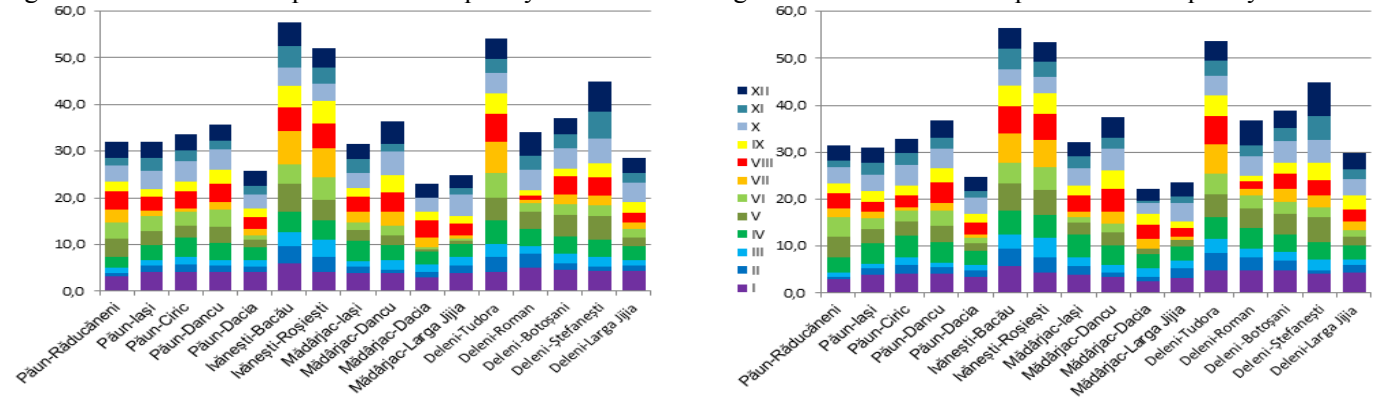

Fig. 11. Thermal inversion phenomena frequency at 03:00 a.m. Fig. 12. Thermal inversion phenomena frequency at 04:00 a.m.
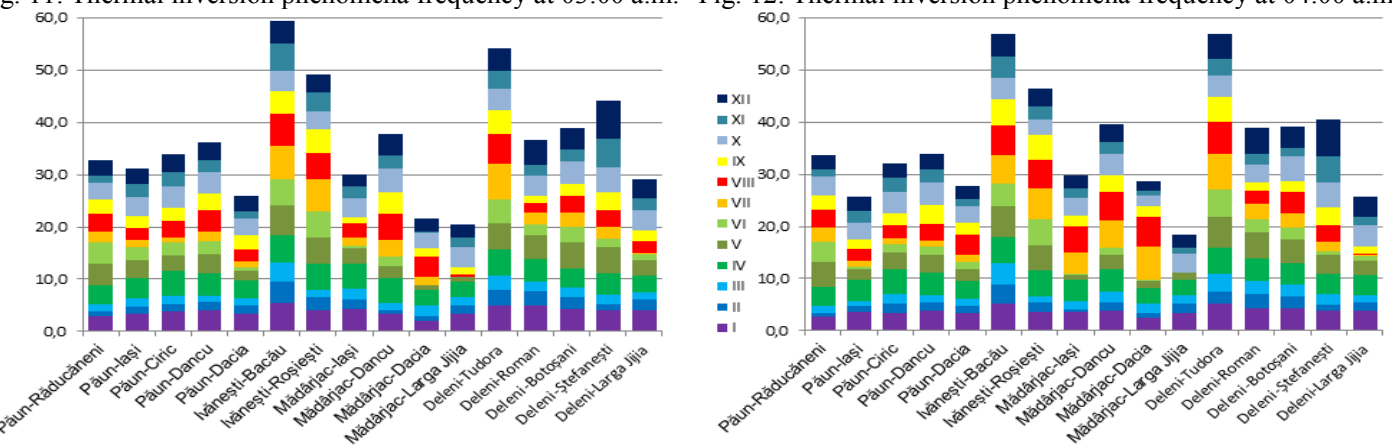

Fig. 13. Thermal inversion phenomena frequency at 05:00 a.m. Fig. 14. Thermal inversion phenomena frequency at 06:00 a.m.

Except Siret valley areas, in the hourly development of thermal inversion we can distinguish Roșiești observation point. This closed micro-drepression character offers ideal conditions for stabilization and sedimentation of cold air which remains trapped in the bottom of the valley.

Lowest thermal inversion phenomenon frequencies are characteristics to open areas with low fragmented relief. An example can be presented in the case of Larga Jijia observation point compared with Mădârjac meteorological station. The 
position of the Larja Jijia observation point located inside the Larja Jijia farm induces a moderate topoclimate, specific to water accumulation. This feature determines low frequencies of thermal inversion phenomenon on this profile.

2.2.2. Thermal inversion phenomenon frequency in the interval 07:00 - 12:00 a.m. With sunrise, the thermal inversion phenomenon frequency gradually decreases. Major difference can be observed from one hour to another. Largest differences are observed in the warm semester where due to the increase of the caloric radiative flow, thermal inversions start easily tobe dissipated by the ascending caloric flow.

In this frequency range the theral inversions falls to the point where stability layer is removed. This development is felt especially when specific radiative inversions related to the summer months, leading most cases to the destruction of the horizontal inversions towards the afternoon.

We also observe it in the situation of Siret river which stands out as an area where the hourly rate decreases slowly, dropping below 30\% just after 11:00. Radiative thermal inversions in the Siret river area that form during summer months especially during August, during which high levels of thermal inversion frequency are preserved.

Winter months, especially in December and January are characterized by high frequencies generated by enhanced stability situations, specific to anticyclones baric formations that impose within the thermal regime through negative air temperature values.

Thermal inversion phenomena generated by dynamic factors particularly those of frontal origin are imposed in the hourly frequencies. Thus, at 11:00 on Ivănești Roșiești profile a total frequence of aproximately $6 \%$ is observed and then again at 12:00 it can be distinguished through a frequency of about $8.8 \%$. One can notice the increase in frequence of thermal inversion formation. The depression landform and the high degree of storage pertaining to this landform form ideal conditions related to preserving the cold air masses within the landform, very difficult to dislodge the warm front passage. 

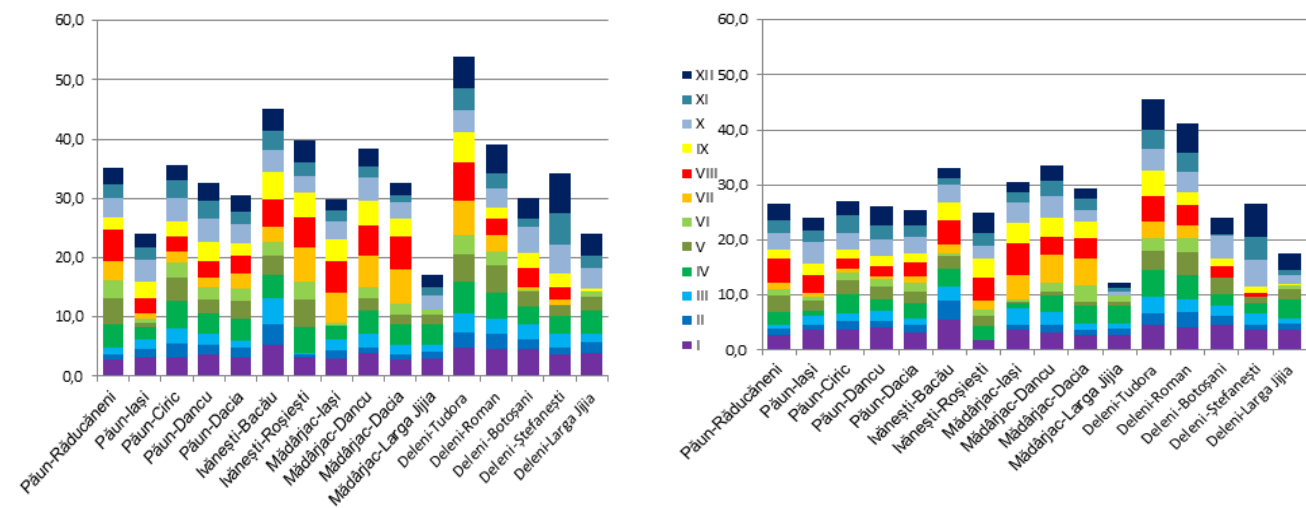

Fig. 15. Thermal inversion phenomena frequency at 07:00

Fig. 16. Thermal inversion phenomena frequency at 08:00
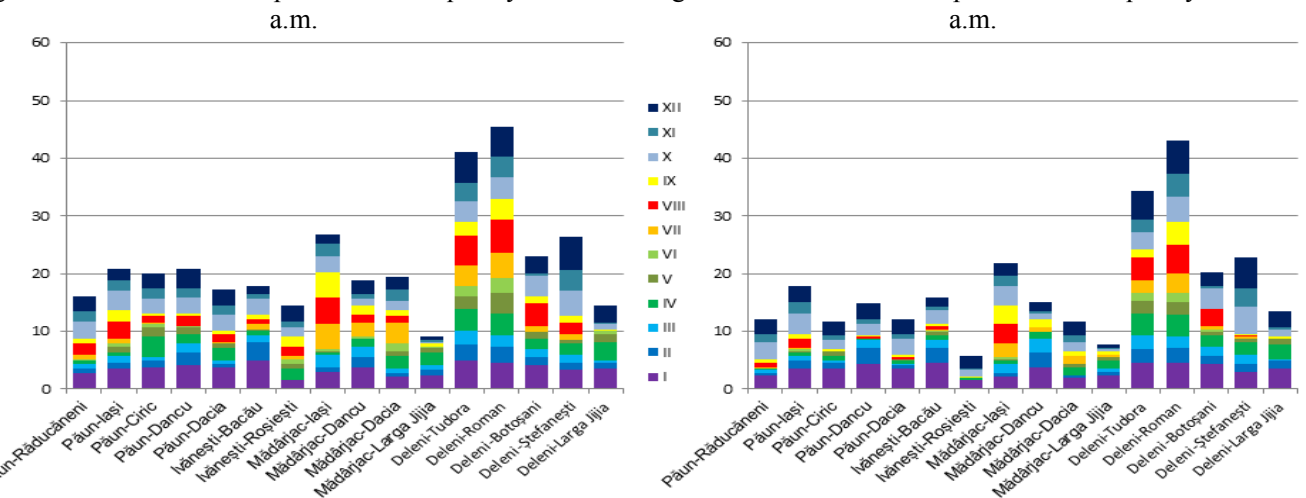

Fig. 17. Thermal inversion phenomena frequency at 09:00

Fig. 18. Thermal inversion phenomena frequency at 10:00
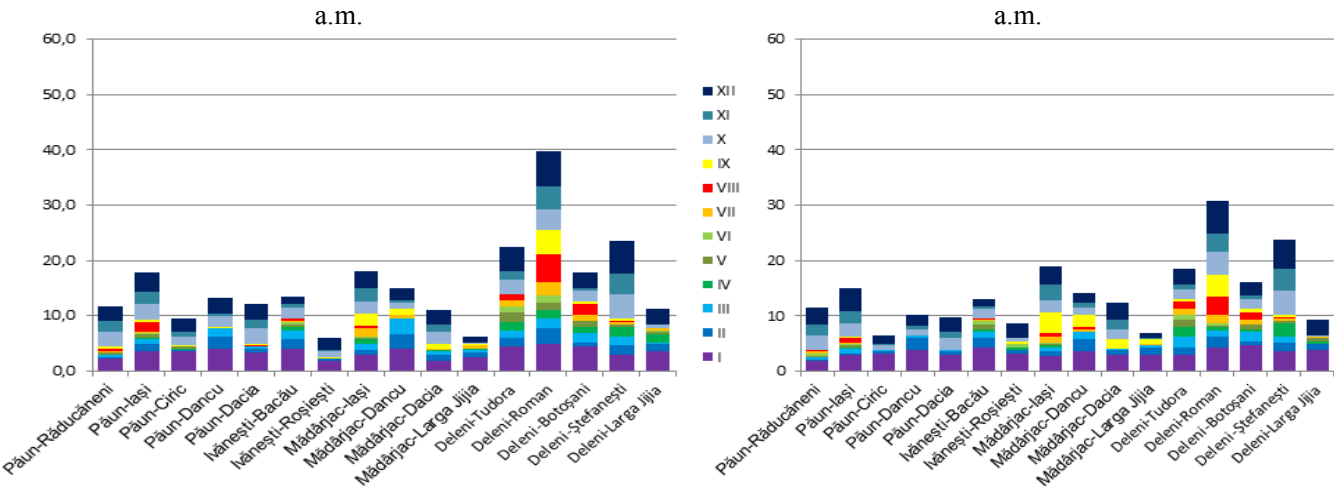

Fig. 19. Thermal inversion phenomena frequency at 11:00 a.m. 
2.2.3. Thermal inversion phenomenon frequency in the interval 13:00 - 18:00 p.m. Between 01:00 to 06:00 the thermal inversion phenomenon decrease in frequency for all calculated profiles. Highest frequencies remain those specific to depression and aisle landforms. Throughout the year during this time interval are dominant convective processes that induce normal stratification of vertical air temperature values, generated by the high radiative heat flow.
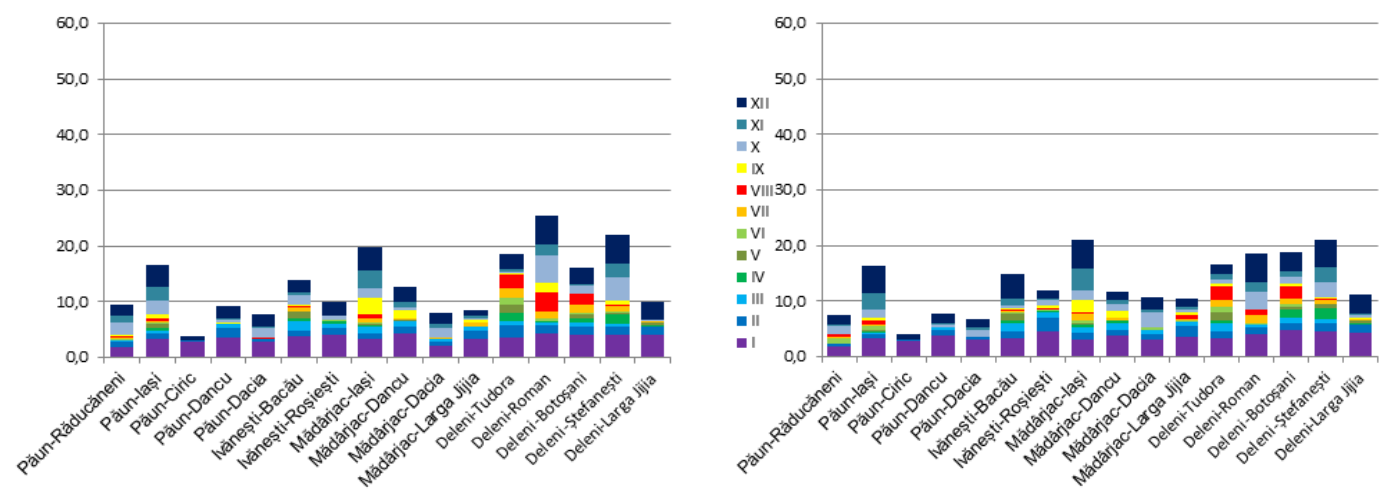

Fig. 21. Thermal inversion phenomena frequency at 13:00 p.m. Fig 22. Thermal inversion phenomena frequency at 14:00 p.m.
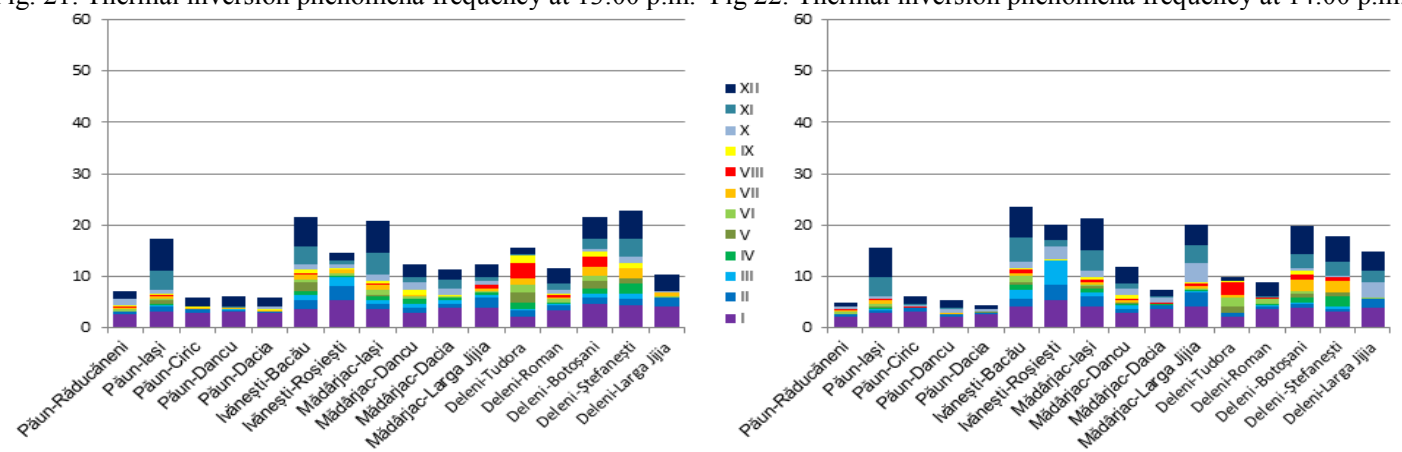

Fig. 23. Thermal inversion phenomena frequency at 15:00 p.m. Fig. 24. Thermal inversion phenomena frequency at 16:00 p.m.
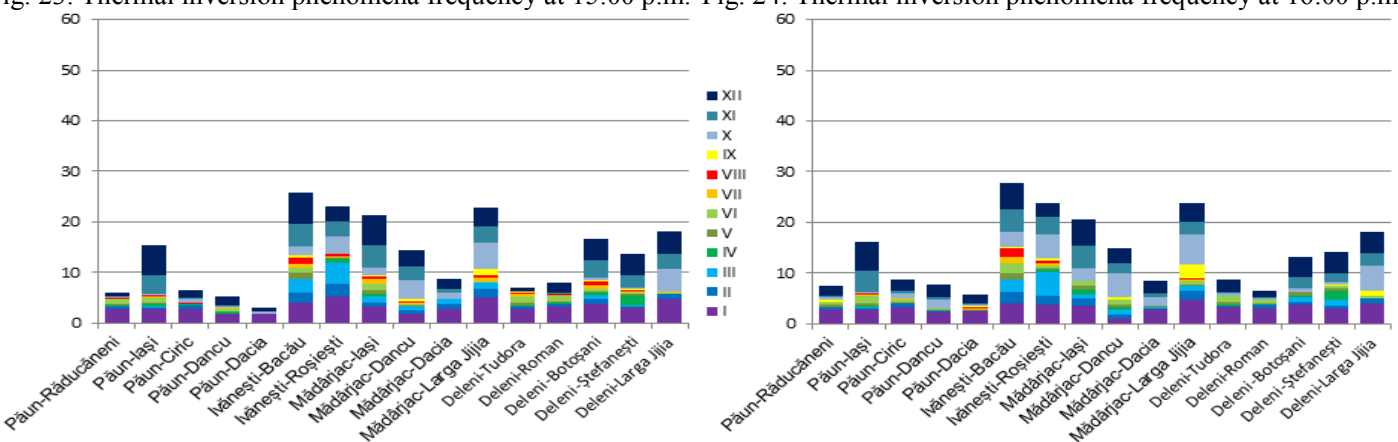

Fig. 25. Thermal inversion phenomena frequency at 17:00 p.m. Fig. 26. Thermal inversion phenomena frequency at 18:00 p.m. 
Largest frequencies of the thermal inversion phenomenon in this time span represent direct consequences of marked atmospheric stability situations and cloud formation during the cold semester.

2.2.4. Thermal inversion phenomenon frequency in the interval 19:00 p.m.00:00 a.m. Along with the decrease in the incidence angle of solar radiation, the intensity of the flux decreases and the caloric radiative heat flow to the end of the day. In atmospheric stabilty conditions the air descends, gradually cooling as it gets

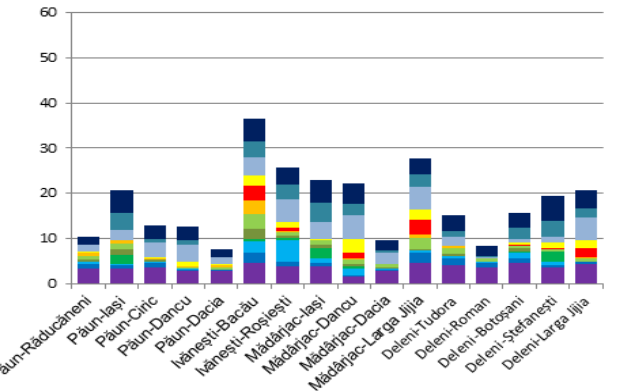

Fig. 27. Thermal inversion phenomena frequency at 19:00 p.m.

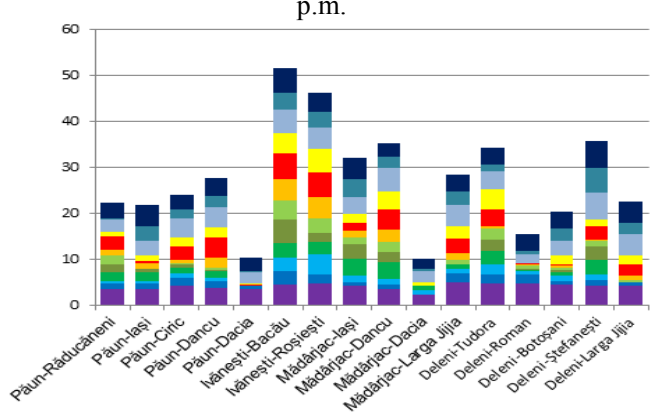

Fig 29. Thermal inversion phenomena frequency at 21:00 p.m.

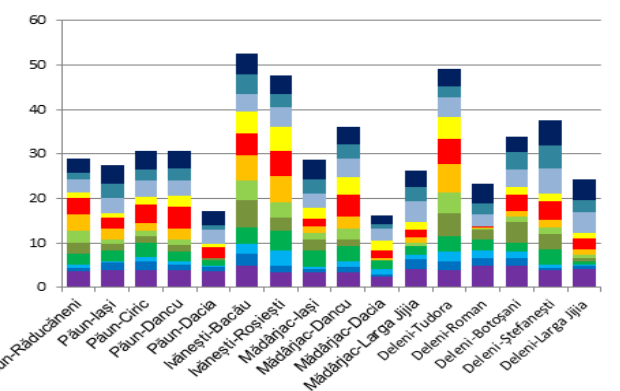

Fig 31. Thermal inversion phenomena frequency at 23:00 p.m.

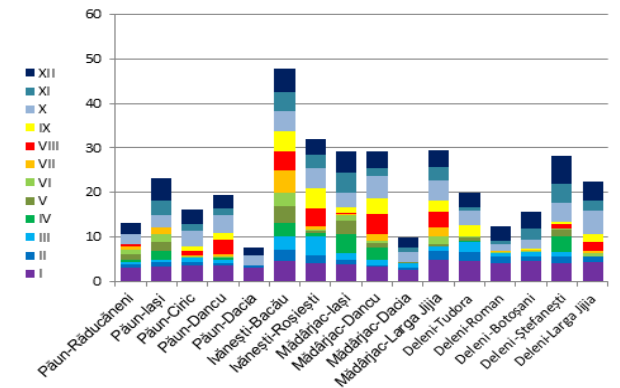

Fig. 28. Thermal inversion phenomena frequency at 20:00 p.m.

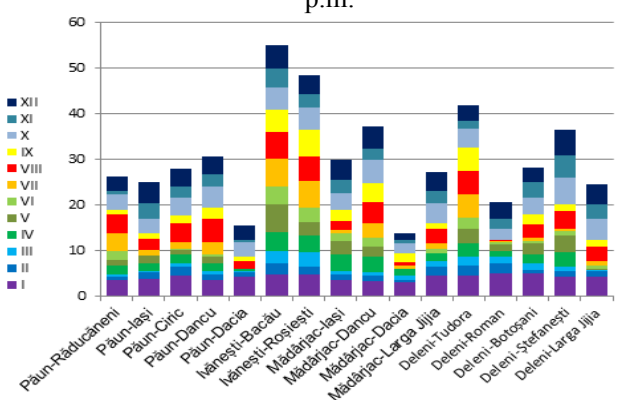

Fig 30. Thermal inversion phenomena frequency at 22:00 p.m.

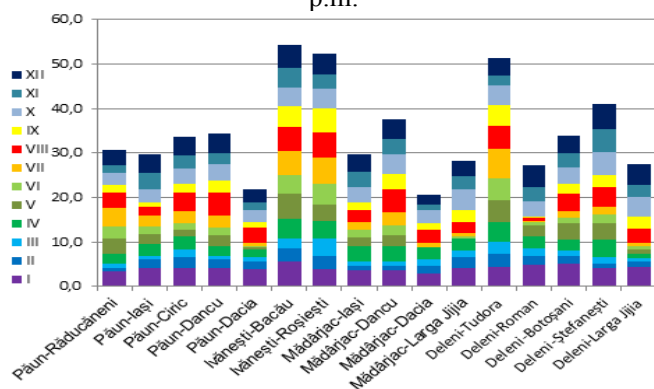

Fig 32. Thermal inversion phenomena frequency at 00:00 a.m. 
lower to the ground. In most cases, compression inversions (sedimentation) increase in frequency towards the second part of the day.

The interval 19:00 - 00:00 is characterized by progressive increase in frequency regarding the thermal inversion phenomenon on all the analyzed profiles. This increase is produced synchronously at all points of observation, approaching specific frequency values specific to 01:00 a.m.

\section{Conclusions}

Mild thermal inversions occured throughout the year with a higher frequency in the cold months of the semester. Still, if they occur during transition seasons they can generate cold waves and frost periods phenomena associated with the occurrence of sudden cooling (rime, glaze, etc).

At regional level it can be distinguished a number of areas where the frequency, duration and intensity of thermal inversion phenomenon manifest itself in different ways. Siret river is highlighted by large frequencies of thermal inversion phenomena that occur throughout the year, reaching the highest frequenies in both montlhy and hourly regime.

Aknowledgement: This work was supported by strategic grand POSDRU 159/1.5/133391, Project "Doctoral and Post-doctoral programs of excellence for highly qualified human resources training for research in the field of Life sciences, Environment and Earth science" cofinaced by the European Social Fund within the Sectorial Operational Program Human Resources Development 2007-2013 .

\section{References}

Ahrens C. D., (1988) - Meteorology Today, West Publish. Co, St. Paul, U.S.A.

Apăvaloae M., Pîrvulescu, I., Apostol, L., (1987), Contribuții la cunoașterea caracteristicilor inversiunilor termice din Depresiunea Rădăuți, , Lucrările seminarului geografic „Dimitrie Cantemir”, nr.7, 1986, Universitatea „Al. I. Cuza”, Iași

Apăvaloae M., Pîrvulescu I., Apostol L., (1988), Caracteristici ale inversiunilor termice din Podișul Fălticenilor, , Lucrările seminarului geografic „Dimitrie Cantemir”, nr.8, 1987, Universitatea „Al. I. Cuza”, Iaşi

Apăvaloae, M., Apostol, L., Pîrvulescu, I., (1990), Caracteristici ale inversiunilor termice din Depresiunea Ciuc, , Lucrările seminarului geografic „Dimitrie Cantemir”, nr.9, 1988, Universitatea „Al. I. Cuza”, Iași

Apăvaloae, M., Apostol, L., (1984), Caracteristicile inversiunilor termice din Depresiunea Dornelor, Lucrările seminarului geografic „Dimitrie Cantemir”, nr.4, 1983, Universitatea „Al. I. Cuza”, Iași 
Apăvaloae, M., Apostol, L., Pîrvulescu, I., (1996), Inversiunile termice din Culoarul Moldovei (sectorul Câmpulung Moldovenesc - Frasin) și influența lor asupra poluării atmosferei, Analele Universității „Ștefan cel Mare”, Suceava, anul 5, secțiunea Geografie-Geologie,

Apostol, L., (1986), Distribuția temperaturilor medii ale lunii ianuarie între Munții Vrancei și Balta Brăilei, Lucrările seminarului geografic „Dimitrie Cantemir”, nr.6, 1985, Universitatea „Al. I. Cuza”, Iași

Bogdan, O., Niculescu, Elena, (1999), Riscurile climatice din România, Editura Academiei Române, București.

Bourne, S. M., (2008) A climate perspective of observed and modeled surfacebased temperature inversions in Alaska, M.S. Thesis, Department of Atmospheric Sciences, University of Alaska Fairbanks, 106 pp. [available on-line at: http://www.uaf.edu/asp/Students/theses/Bourne SM.pdf]

Bourne, S., M., Bhatt, U.,S., Zhang, J., Thoman, R., (2010), Surface-based temperature inversions in Alaska from a climate perspective, ELSEVIER, Atmospheric Research 95

Bradley, R., S., Keimig, F., T., Diaz, H., F., (1992), Climatology of surface-Based Inversions in the North American Arctic, Journal of geophysical research, vol. 97, no.D14, pag., 15,699 - 15,712

Erhan Elena, (1981), Contribuții la studiul inversiunilor de temperatură din Depresiunea Câmpulung Moldovenesc, Lucrările seminarului geografic „Dimitrie Cantemir”, nr.1, 1980, Universitatea „Al. I. Cuza”, Iași

Frăsineanu, M., (2004), Influenţa culoarelor de vale asupra elementelor climatice in Carpaţii de Curbură, Analele Universității „Spiru Haret”, Seria Geografie. Nr.7, Editura Fundației România de mâine, București

Linacre, Edward, Geerts, Bart, (1997), Climates and Weather Explained, Routledge, London and New York

Matveev L. T. (1958), Meteorologie generală, tradus de Th. Mândrescu, București 1964

Oke, T. R., (1987) , Boundary Layer Climates, Second Edition, reprinted 2006, Routledge, New York, U.S.A.

Sandrine Anquetin, Claude Guilbaud, Jean-Pierre Chollet, (1999), Thermal valley inversion impact on the dispersion of a passive pollutant in a complex mountainous area, Atmospheric Environment, Volume 33, Issues 24-25, October 1999, Pages 3953-3959

Sfîcă, L., (2009), TEZA DE DOCTORAT:Culoarul Siretului: Studiu climatic. Universitatea "Al. I. Cuza", Iaşi.

*** (2008), Clima României, Administraţia Naţională de Meteorologie, Editura Academiei Române.

***http://www.logtagrecorders.com/products/pdf/LogTag_HAXO-

8 Product Specification.pdf

***http://www.davisnet.com/product_documents/weather/manuals/VP_Console.pdf 